This item was submitted to Loughborough's Research Repository by the author.

Items in Figshare are protected by copyright, with all rights reserved, unless otherwise indicated.

\title{
Financial markets' shutdown and reaccess
}

\section{PLEASE CITE THE PUBLISHED VERSION}

https://doi.org/10.1111/ecin.12518

\section{PUBLISHER}

Wiley @ Western Economic Association International

\section{VERSION}

AM (Accepted Manuscript)

\section{PUBLISHER STATEMENT}

This is the peer reviewed version of the following article: AGNELLO, L., CASTRO, V. and SOUSA, R.M., 2018. Financial markets' shutdown and reaccess. Economic Inquiry, 56 (1), pp. 562-571, which has been published in final form at https://doi.org/10.1111/ecin.12518. This article may be used for non-commercial purposes in accordance with Wiley Terms and Conditions for Use of Self-Archived Versions.

\section{LICENCE}

CC BY-NC-ND 4.0

\section{REPOSITORY RECORD}

Agnello, Luca, Vitor Castro, and Ricardo M. Sousa. 2017. "Financial Markets' Shutdown and Reaccess". Loughborough University. https://hdl.handle.net/2134/26417. 


\title{
Financial Markets' Shutdown and Re-Access ${ }^{*}$
}

\author{
Luca Agnello ${ }^{\dagger}$ \\ Vítor Castro ${ }^{\ddagger}$ \\ Ricardo M. Sousa ${ }^{\S}$
}

\begin{abstract}
We employ a discrete-time parametric duration model on a group of 121 countries over the period 1970-2011 and find that the probability of the end of financial markets' shutdown and re-access falls as these events become longer. We also show that: (i) shutdown episodes are longer when economic prospects are poor and the degree of financial openness falls, the chief executive has been in office for long periods, and the country has a default history; and (ii) spells of re-access tend to be longer when economic growth improves and financial openness increases, there are neither government crises nor government instability, and the country did not default in the past.
\end{abstract}

Keywords: Financial markets' shutdown, financial markets' re-access, parametric duration model.

JEL codes: C41, G15.

\footnotetext{
* We are grateful to participants to the Finance and Economics Conference organized in Munich on 13-15 August 2014, the 4th International Symposium in Computational Economics and Finance (ISCEF) organized in Paris on April 14-16 2016 (http://www.iscef.com), the Editor, Wesley Wilson, the Guest Editors, Bruce McGough and Fredj Jawadi, and an anonymous reviewer for their constructive comments and suggestions that considerably improved this paper. Castro and Sousa acknowledge that this work was carried out within the funding with COMPETE reference $\mathrm{n}^{\circ}$ POCI-01-0145-FEDER-006683, with the FCT/MEC's (Fundação para a Ciência e Tecnologia, I.P.) financial support through national funding and by the ERDF through the Operational Programme on "Competitiveness and Internationalization COMPETE 2020" under the PT2020 Partnership Agreement.

${ }^{\dagger}$ University of Palermo, Faculty of Economics, Department of Economics, Business and Statistics, Viale delle Scienze, 90128 Palermo, Italy. Email: luca.agnello01@unipa.it.

₹ Loughborough University, School of Business and Economics, Loughborough, Leicestershire LE11 3TU, United Kingdom; University of Minho, Economic Policies Research Unit (NIPE), Campus of Gualtar, 4710-057 - Braga, Portugal. Email: V.M.Q.Castro@lboro.ac.uk.

${ }^{\S}$ University of Minho, Department of Economics and Economic Policies Research Unit (NIPE), Campus of Gualtar, 4710-057 - Braga, Portugal; London School of Economics and Political Science, LSE Alumni Association, Houghton Street, London WC2 2AE, United Kingdom. E-mails: rjsousa@eeg.uminho.pt, rjsousa@alumni.lse.ac.uk.
} 


\section{Introduction}

Why are some countries able to access financial markets immediately after a default episode, while others seem to be punished and face the prospects of a long shutdown from the markets?

While some works have devoted attention to investigate the question of when a country will re-gain markets’ access (IMF, 2001, 2003), the question of how long it will be shut out from financial markets once a period of default occurs has not been examined yet.

Access to financial markets is important from three main reasons. First, it plays an important role in many countries, as several investment projects on infrastructure and capacity-building are typically financed via assistance from development banks, borrowing from international financial markets or overseas aid. Second, potential lenders can "keep track" of the behaviour of borrowers during default periods and contribute to the evaluation of whether new funds should be provided or not. Third, investigating this question can help designing policies aimed at guaranteeing continued market access for longer periods and at providing a better assessment of market-based borrowing.

Despite this, sovereign defaults are not costless, and the knowledge of the period of markets' shutdown and the costs associated with it can influence the decision and the timing of default. For instance, if the economic impact is small and the punishment is temporary, defaults will be more likely to happen. ${ }^{1}$

In this paper, we use data for a sample of 121 countries over the period 19702011 and rely on a discrete-time version of the Weibull duration model to: (i) test whether the likelihood of financial markets' shutdown and re-access ending changes as

\footnotetext{
${ }^{1}$ To witness it, many governments adopted fiscal austerity measures during the Great Recession (Agnello et al., 2012; Cimadomo, 2012).
} 
they become longer; and (ii) to assess the impact of economic, political and circumstantial factors on the duration of episodes of markets' shutdown and re-access.

Our duration variable of interest is defined as the number of years over which a country is shut out from or gains re-access to (international) financial markets. Specifically, we consider that net negative bank or bond transfers from private creditors to either the public and the publicly guaranteed sector or the private sector imply a market shutdown. By contrast, positive net transfers denote periods of market re-access.

Our results show that the likelihood of the end of financial markets' shutdown and re-access after a certain duration falls as these events become longer. The empirical findings also highlight the important role that the economic growth, the financial openness, the political (in)stability and the default history play on the duration of markets' shutdown and re-access. More specifically, markets' shutdown episodes are longer when economic prospects are poor and the degree of financial openness falls, the chief executive has been in office for long periods, and the country has a default history. As for the spells of re-access to international financial markets, they tend to be longer when economic growth improves and financial openness increases, there are neither government crises nor government instability, and the country did not default in the past.

The rest of the paper is organized as follows. Section 2 reviews the existing literature on the duration of financial markets' shutdown and re-access. Section 3 presents the econometric model and the empirical methodology. Section 4 describes the data and discusses the results. Finally, Section 5 concludes. 


\section{Literature Review}

Why do sovereign governments avoid defaults? Traditionally, two types of penalties (costs) associated with default episodes have been investigated: (i) direct sanctions (Bulow and Rogoff, 1989; Fernandez and Rosenthal, 1990); and (ii) reputational costs (Eaton and Gersovitz, 1981; Eaton, 1996; Cole and Kehoe, 1997). Direct sanctions are usually seen as an interference with current transactions either via denial of trade credit or seizure of foreign assets.

Another strand of the literature emphasizes the costs of default for the domestic economy (Catão and Kapur, 2006). The main argument is that default causes broad 'collateral damage’ on the debtor’s government or its economy.

There is also a line of investigation focusing on the determinants of public debt and its composition in developing and emerging countries. Claessens et al. (2007) highlight the importance of the country size, the fiscal burden and the quality of the institutional framework as having a positive effect on the development of the bond market. Borensztein et al. (2008) distinguish between the determinants of corporate, financial sector and government bond markets, and emphasize the role played by the lack of capital controls, the privatization of the pension system and the degree of trade openness.

As can be inferred from the discussion above, the majority of the works on sovereign debt look at the determinants of government debt or the reasons why governments may want to repay their obligations, but has typically ignored the question about the issue of how long countries are shut out from international financial markets after defaulting and how (and for how long) they manage to borrow again at some point in the future. For instance, the seminal paper by Eaton and Gersovitz (1981) argues that governments repay their debt because future lending depends on reputation. Arellano 
(2008) models exclusion from international financial markets after defaulting as a stochastic number of periods, with re-access occurring with an exogenous probability, or independent of both global financial conditions and country-specific conditions. Lensink and van Bergeijk (1991) investigate the determinants of a country’s ability to access international financial markets by focusing on whether a country has undertaken actual borrowing.

In this context and for the main purpose of our paper, the duration analysis gains an important relevance. In economics, it started to be employed to assess the duration of unemployment spells and business cycles or (Sichel, 1991; Zuehlke, 2003; Castro, 2010). ${ }^{2}$ More recently, Agnello et al. (2013) make use of this analysis to assess the determinants of the duration of fiscal consolidation programs, while Agnello et al. (2015) apply it to the identification of the drivers of the duration of periods of booms, busts and normal times in the housing markets. Agnello et al. (2017) also rely on it to study the "legacy" and the "tyranny" of time on the exit and the re-entry of sovereigns to international capital markets.

\section{Econometric model}

If $T$ measures the uncensored time of the occurrence of the event i.e. the length of the event in time units, then, $t_{1}, t_{2}, \ldots, t_{\mathrm{n}}$ represent the observed duration of the markets’ shutdown (or the markets' re-access).

A particularly useful function for duration analysis is the hazard function, $h(t)=f(t) / S(t)$, where $f(t)$ is the density function and $S(t)$ denotes the survivor function. This function measures the rate at which markets' shutdown (re-access) spells

\footnotetext{
${ }^{2}$ See Allison (1982), Kiefer (1988) and Castro (2010) for a review of the literature on economic duration analysis.
} 
will end at time $t$, given that they lasted until that moment, that is, it is the probability of exiting from a state in moment $t$ conditional on the length of time in that state.

A popular functional form of the hazard function is the continuous-time "Weibull model", i.e. $h(t, x)=h_{0}(t) \exp (\mathbf{x} \boldsymbol{\beta})=\gamma p t^{p-1} \exp (\mathbf{x} \boldsymbol{\beta})$, where $h_{0}(t)$ is the baseline hazard function that captures the data dependence of duration, $p$ parameterizes the duration dependence, $t$ denotes time and measures exclusively the total length or the full time span of the event, $\gamma$ is a constant, $\boldsymbol{\beta}$ is a $(\mathrm{k} \times 1)$ vector of parameters that need to be estimated, $\mathbf{x}$ is a vector of covariates, $p>0$ and $\gamma>0$. If $p>1$, the conditional probability of a market shutdown (re-access) ending in moment $t$ increases as the phase gets longer, i.e. there is positive duration dependence; if $p<1$ there is negative duration dependence; finally, there is no duration dependence if $p=1$. Therefore, by estimating $p$, we can test for duration dependence in markets' shutdown.

However, such continuous-time framework does not allow for the inclusion of time-varying covariates. Prentice and Gloeckler (1978) develop a discrete-time version of the proportional hazards model, with the respective discrete-time hazard function being given by:

$$
\begin{aligned}
P_{i t}=\operatorname{Pr}\left[T_{i}\right. & \left.=t \mid T_{i} \geq t, \mathbf{x}_{i t}\right]=1-e^{-h_{t} e^{\beta} x_{i t}}=1-e^{-e^{\lambda_{t}+\beta^{\prime} x_{i t}}}, \\
& \Leftrightarrow \ln \left[-\ln \left(1-P_{i t}\right)\right]=\lambda_{t}+\boldsymbol{\beta}^{\prime} \mathbf{x}_{i t},
\end{aligned}
$$

where $t$ denotes the moment in time when the value of each independent variable is observed. As time is discrete, $t$ corresponds to the amount of time (measured in years) during which the event has been "running" or has been "active", i.e. the amount of time since the beginning of the event or the time span. ${ }^{3}$ This model is equivalent to the

\footnotetext{
${ }^{3}$ Countries do not experience a shutdown from (or a re-access to) international financial markets at the same time: sometimes, there is partial overlapping; other times, such overlapping does not occur. Consequently, we have different starting points for the events/spans across countries. However, over the sample period, several events/spans start and finish at different points in time and for different countries. Following Prentice and Gloecker (1978), time is assumed to take only integer values. In addition, we assume that $n$ independent spells of markets' shutdown or markets' re-access starting at $t=1$ are observed.
} 
complementary log-log (or cloglog) function, where $\lambda_{t}\left(=\ln h_{t}\right)$ represents the logarithm of an unspecified (baseline hazard) function of time and $\mathbf{x}_{i t}$ is a vector of time-varying explanatory variables.

One suitable and quite popular specification for $\lambda_{t}$ is the discrete-time analogue to the continuous-time Weibull model, which yields:

$$
\lambda_{t}=\ln h_{t}=\alpha+(p-1) \ln t
$$

where $t$ where $t$ denotes the moment in time - as time is discrete - that the value of each independent variable is observed. ${ }^{4}$

Prentice and Gloeckler (1978) and Allison (1982) show that discrete-time loglikelihood function for a sample of $i=1, \ldots, n$ spells can be written as follows:

$$
\ln L=\sum_{i=1}^{n} \sum_{j=1}^{t_{i}} y_{i t} \ln \left(\frac{P_{i j}}{1-P_{i j}}\right)+\sum_{i=1}^{n} \sum_{j=1}^{t_{i}} \ln \left(1-P_{i j}\right),
$$

where the dummy variable $y_{i t}$ is equal to 1 if the shutdown from (or re-access to) the markets of country $i$ ends at time $t$, and 0 otherwise. We estimate this model by Maximum Likelihood, while substituting $P_{i j}$ by (1) and $\lambda_{t}$ by (2), which implies that the discrete-time log-likelihood function will be conditional on both time and the conditions observed for the different control variables at time $t$.

Such observation continues until time $t+i$, at which point either an event occurs or the observation is censored, i.e. the event is observed at $t+i$, but not at $t+i+1$. Finally, a vector of time-varying explanatory variables $\mathbf{x}_{i t}$ is also observed.

${ }^{4}$ Note that $\lambda_{t}=\ln h_{t}=\ln \left(\gamma p t^{p-1}\right)=\alpha+(p-1) \ln t$, with $\alpha=\ln (\gamma p)$ and $t=$ DurMktShutDown or $t=$ DurMktReAccess. To include time-varying covariates in the discrete-time duration model, we gathered data for each regressor (i.e. control variable) at time (i.e. year) $t$. However, for $\lambda_{t}$, we measure the time since the beginning of the event/span. For example, if there is a market shutdown that lasts from 1991 until 2000, $\lambda_{t}$ will be equal to 1 for 1991, 2 for 1992,..., and 10 for 2000. In practice, we identify the span/event of interest and compute its length/duration while, in the case of time-varying regressors, these are observed at each year $t$. This implies that, even though the beginning of a specific span/event may occur at any particular date, the discrete-time hazard rate of a markets' shutdown (or a markets' re-access) varies systematically over time instead of being arbitrary. 


\section{Data and Empirical Results}

\subsection{Data}

The data used in the duration analysis consists of spells, which, in our study, represent the number of years of financial markets' shutdown (DurMktShutDown). For each of the 121 countries included in our sample, annual data over the period 1970-2011 on borrowing are collected from the Global Development Finance - World Development Indicators (GDF-WDI) database of the World Bank and used to measure the degree of a country's shutdown from (or a re-access to) international financial markets.

Our baseline model includes a set of economic, political and circumstantial variables. The economic indicators are:

- GDP growth rate (GDP): Economic fundamentals significantly impact on the investment climate and low growth rates signal economic vulnerability. In countries experiencing adverse economic conditions, both private and foreign investors refrain from investing. This, combined with the increasing borrowing costs through syndicated loans or bond issuances, significantly reduce the country's ability to borrow, forcing it to satisfy its financing needs less frequently via the international financial markets. The GDP series are obtained from the World Bank's WDI database.

- Trade as percentage of GDP (Trade): It measures the degree of openness of a country. A decline in the exchanged volumes with trade partners is a symptom of the country's difficulty to borrow. As a result of the lack of confidence on the ability to repay their debt, countries could be banned from placing their products abroad, which leads to a collapse of exports. 
- Financial openness (FinOpen): This is an index that measures a country's degree of openness of the capital account (Ito and Chinn, 2012). It codifies the intensity of capital controls on cross-border financial transactions based on the information from the IMF's Annual Report on Exchange Arrangements and Exchange Restrictions (AREAER). More liberalized financial markets should alleviate the liquidity risk and reduce the probability of shutdown of international financial markets for prolonged periods.

The stability of the political environment may also play a key role on the timing and the circumstances under which countries are shut out from the markets or re-gain market access. To capture this effect, we have considered three indicators:

- Years in Office (YrsOffice): It measures the number of years the chief executive has been in office and it is provided by the Database of Political Institutions (DPI) of the World Bank. The policy horizon of the government officials is an important determinant of the borrowing decision process. The shorter the period a chief executive expects to be in office, the more likely he will take actions that yield short-run benefits at the expenses of significant long-run costs. In particular, the immediate benefits of higher loans might come at the price of accepting unfavourable borrowing conditions and being subject to future sanctions for not repaying the debt.

- Government crises (GovCrises): This variable counts the number of any rapidly developing situation that might lead to the fall of the current regime and remove a particular government from power with the exclusion of situations of revolt. It is retrieved fro the Cross-National Time-Series Data Archive (CNTS). Countries facing more government crises will have more 
difficulties in terms of access to the financial markets, implying that they may be excluded from that access for longer periods.

- Regime durability (RegimeDur): This variable counts the number of years that a cabinet has been in power, up to the current year. A cabinet that falls during its first year in power is counted as 1 . Every time there is a government termination, the variable is reset to 1 the year after the termination. It comes from the Polity IV Database. Countries characterized by more stable political regimes benefit from an higher reputation at the international level and this makes it easier to borrow on financial markets.

Two additional variables are used to control for circumstantial factors, namely:

- Default history (DefaultHist): Debt repudiation generally results in a shutdown from the international financial markets. In particular, in the absence of a credible debt restructuring process (eventually supported by international institutions), financial markets discriminate, in terms of access, between defaulters and non-defaulters. To assess whether discrimination has long-lasting effects or not, we include a dummy variable tracking episodes of default. Based on the chronology of the selective default rating as compiled by the Standard \& Poors (2013), this dummy variable takes the value of one during the years of default and zero otherwise.

- IMF program (IMFProg): This is a dummy variable that controls for whether a country is under an agreement with the IMF (either by Stand-By Arrangements, Extended Fund Facilities or Poverty Reduction and Growth Facility programs) or not. It assesses the role played by the multilateral financial assistance provided by the IMF as a means for overcoming liquidity problems by facilitating the country's access to financial markets. The 
information about the timing of IMF-supported programs is extracted from the Monitoring of Fund Arrangements (MONA) database of the IMF.

By organizing the data in spells - where a spell represents the number of years that a country is shut out from the financial markets (DurMktShutDown) - we are able to identify 561 episodes, generating 1989 observations for our discrete-time duration analysis. ${ }^{5}$ These descriptive statistics are summarized in Table 1 , where further details about the regressors employed in the duration analysis are also presented.

\section{[ INSERT TABLE 1 HERE. ]}

Looking at the distribution of the events under investigation (Table 2), we note that African countries are excluded from financial markets for substantially longer periods than other regions. Latin American countries follow in the rank. The evidence for the North American region is not particularly significant given the limited number of countries belonging to this group. The statistics reported in Table suggest that, overall, re-gaining access to the financial markets is more difficult than being shut out. In fact, the frequency of financial markets' shutdowns is almost three times higher than the frequency of market re-access. This notably applies to the African and Latin American economies. Interestingly, the European countries seem to be particularly resilient to market shutdowns. For OECD countries, the distribution of the events is substantially balanced with the frequency of market shutdowns being slightly higher than the frequency of market re-accesses.

\section{[ INSERT TABLE 2 HERE. ]}

\footnotetext{
${ }^{5}$ For the duration of financial markets' re-access (DurMktReAccess), we identify 324 spells (i.e. 684 observations).
} 
Table 3 reports the frequency of markets' shutdown conditional on the occurrence of sovereign default. It suggests that defaults increase the frequency (and therefore, the probability) of a country being shut out from the markets.

\section{[ INSERT TABLE 3 HERE. ]}

\subsection{Markets' shutdown}

The empirical evidence that emerges from the estimation of the discrete-time version of the Weibull model for the duration of market shutdowns is summarized in Table 4. The results provide strong evidence that the likelihood of a market shutdown ending decreases as it becomes longer (see Column 1).

In Column 2, we allow for the effects of economic factors. The empirical findings show that higher GDP growth and higher financial or capital openness contribute to a significant decrease in the length of markets' shutdown. However, the degree of trade openness is negatively related with the likelihood of markets' shutdown ending. Given that the coefficient on Trade is no longer statistically significant when other control variables are added to the model, this indicates that the degree of trade openness might not be as important as GDP growth and financial openness. Columns 3 and 4 corroborate this argument.

In Column 3, some political variables are included in the model, but only the number of years the chief executive is in office has proved to influence significantly the duration of markets' shutdown: the longer the chief executive is in office, the lower the likelihood of a market shutdown ending. This shows that a change in government might be necessary to create the necessary conditions to pay its loans and, ultimately, to re- 
gain access to the markets. However, no significant effects are observed in the case of the number of government crises and the duration of the political regime.

Additional explanatory variables like the history of default and the external intervention from the IMF are considered in Column 4. The results point to the importance of the default history, but do not suggest a significant role for the presence of an IMF program. ${ }^{6}$

Finally, in Column 5, we restrict the analysis to the regressors with significant coefficients. The results confirm and reinforce the importance of the economic growth, the financial openness, the number of years in office and the default history on the duration of markets' shutdown.

\section{[ INSERT TABLE 4 HERE. ]}

\subsection{Markets' re-access}

The results for markets' re-access are presented in Table 5 and also point to the fact that the longer a country has re-gained market access, the lower the likelihood of being excluded from it (see Column 1).

Then, we allow for the effects of economic, political and circumstantial factors (Columns 2, 3 and 4, respectively). The results indicate that, to keep its access to the markets, the economic environment is crucial: a higher growth rate of GDP is negatively linked with the likelihood of a country losing its access to financial markets. Similarly, an increase in the degree of financial or capital openness reduces the likelihood of markets’ re-access ending; and, once again, Trade is not significant.

\footnotetext{
${ }^{6}$ We also considered different types of programmes (extended credit facilities, stand-by arrangements and extended fund facilities), but no significant results were found. This empirical evidence is available upon request.
} 
Regarding the political control variables, we observe that it is mainly the number of government crises that drives the duration of market re-access. More specifically, the higher the number of government crises in a year, the higher the likelihood of markets' re-access ending. Thus, political instability makes it more difficult for a sovereign to obtain funding in the financial markets.

Additionally, we find that the default history leads to a fall in the duration of markets’ re-access. However, no significant effects are found regarding the eventual gains from the implementation of an IMF programme.

In the last regression, we restrict the analysis to those regressors that present significant coefficients. The results sustain the importance of economic growth, financial openness, government instability and default history on the duration of market re-access.

\section{[ INSERT TABLE 5 HERE. ]}

\subsection{Robustness check}

As the economic environment - in particular, the GDP growth rate - has proved to be one of the most relevant factors for both the duration of markets' shutdown and markets' re-access, in this Section, we provide a more extensive analysis of the role played by economic growth.

Table 6 summarizes the changes of GDP growth (on average) during the reaccess times. It shows that markets' re-access is generally associated to a significant improvement in economic fundamentals.

[ INSERT TABLE 6 HERE. ] 
In Table 7, we distinguish between the situation where the GDP growth rate is higher or lower than zero and the case where the GDP growth rate is higher or lower than the average. We start by looking at the results for markets' shutdown. They show that the positive impact of the economic growth on the likelihood of markets' shutdown ending is more relevant when the growth rate is positive (Column 1), but not significant when the growth rate is negative. Similarly, when we consider the average growth rate as the threshold, we observe a statistically significant (and positive) impact only when the growth rate is above its mean (Column 2).

The results are quite similar for markets' re-access, but with the obvious symmetric signs. The likelihood of markets’ re-access ending decreases when the GDP growth rate is positive, but no significant effects are found for negative growth rates (Column 3). However, economic growth seems to impact in a significantly negative manner the duration of markets' re-access both when the GDP growth rate is above and below the average.

All in all, these findings suggest that the economic environment is particularly relevant when the economy is growing. This reduces the duration of markets' shutdown and raises the duration of markets' re-access.

[ INSERT TABLE 7 HERE. ]

\section{Conclusion}

In this paper, we build on a database of episodes of markets' shutdown and markets' re-access, and employ a discrete-time version of a Weibull duration model allowing for the presence of economic, political and circumstantial effects. 
Using data for 121 countries over the period 1970-2011, we show that the likelihood of the end of such episodes after a certain duration decreases the longer they last.

Regarding the additional control variables, we show that economic growth, financial openness, political (in)stability and the default history are the main drivers of the duration of markets' shutdown or markets’ re-access.

In the one hand, markets' shutdown episodes tend to be longer when: (i) economic growth and financial openness fall; (ii) the chief executive has been in office for long periods; and (iii) the country has a history of defaults. On the other hand, markets' re-access spells are longer when: (i) economic growth and financial openness increases; (ii) there are neither government crises nor government instability; and (iii) the country does not have a history of defaults.

\section{References}

Agnello, L., Castro, V., and R.M. Sousa, 2013. What determines the duration of a fiscal consolidation program? Journal of International Money and Finance, 37, 113-134.

Agnello, L., Castro, V., and R.M. Sousa, 2015. Booms, busts and normal times in the housing market, Journal of Business \& Economic Statistics, 33(1), 25-45.

Agnello, L., Castro, V., and R.M. Sousa, 2017. The legacy and the tyranny of time: Exit and re-entry of sovereigns to international capital markets. University of Minho, manuscript.

Allison, P., 1982. Discrete-time methods for the analysis of event histories. Sociological Methodology, 13, 61-98.

Arellano, C., 2008. Default risk and income fluctuations in emerging economics. American Economic Review, 98(3), 690-712.

Borensztein, E., Cowan, K., Eichengreen, B., and U. Panizza, 2008. Prospects for Latin American bond markets: A cross-country view. In: Borensztein, C., Eichengreen, B., and U. Panizza, Eds. Bond Markets in Latin America: On the verge of a Big Bang? MIT Press: Cambridge (MA). 
Bulow, J., and K. Rogoff, 1989. Sovereign debt: Is it to forgive to forget? American Economic Review, 79(1), 43-50.

Castro, V., 2010. The duration of economic expansions and recessions: More than duration dependence. Journal of Macroeconomics, 32, 347-365.

Catão, L., and S. Kapur, 2006. Volatility and the debt-intolerance paradox. IMF Staff Papers, 53(2).

Cimadomo, J., 2012. Fiscal policy in real time. Scandinavian Journal of Economics, 114(2), 440-465.

Claessens, S., Klingebiel, D., and S. Schmuckler, 2007. Government bonds in domestic and foreign currency: The role of macroeconomic and institutional factors. Review of International Economics, 15, 370-413.

Cole, H., and P. Kehoe, 1997. Reviving reputation models of international debt. Federal Reserve Bank of Minneapolis Quarterly Review, 21, 21-30.

Eaton, J., 1996. Sovereign debt, reputation and credit terms. International Journal of Finance \& Economics, 1, 25-35.

Eaton, J., and M. Gersovitz, 1981. Debt with potential repudiation: Theoretical and empirical analysis. Review of Economic Studies, 48(2), 289-309.

Fernandez, R., and R.W. Rosenthal, 1990. Strategic models of sovereign-debt renegotiations. Review of Economic Studies, 57, 331-349.

International Monetary Fund, 2001. Assessing the determinants and prospects for the pace of market access by countries emerging from crises. Prepared by the Policy Development and Review Department.

International Monetary Fund, 2003. Access to international capital markets for firsttime sovereign issuers. Prepared by the International Capital Markets Department.

Ito, H., and M. Chinn, 2012. Notes on the Chinn-Ito Financial Openness Index 2010 update. Portland State University, Working Paper.

Kiefer, N., 1988. Economic duration data and hazard functions. Journal of Economic Literature, 26, 646-679.

Lensink, R., and P. van Bergeijk, 1991. The determinants of developing countries' access to the international capital market. Journal of Development Studies, 28(1), 86103.

Prentice, R., and L. Gloeckler, 1978. Regression analysis of grouped survival data with application to the breast cancer data. Biometrics, 34, 57-67. 
Sichel, D., 1991. Business cycle duration dependence: A parametric approach. Review of Economics and Statistics, 73, 254-260.

Zuehlke, T., 2003. Business cycle duration dependence reconsidered. Journal of Business and Economic Statistics, 21, 564-569.

\section{List of Tables}

Table 1. Descriptive statistics.

\begin{tabular}{lccccc}
\hline Variables & Obs. & Mean & S.D. & Min. & Max. \\
\hline DurMktShutDown & 1989 & 4.18 & 4.07 & 1 & 30 \\
DurMktReAccess & 684 & 2.24 & 1.70 & 1 & 11 \\
GDP & 1898 & 3.53 & 5.31 & -27.16 & 34.5 \\
Trade & 1897 & 58.43 & 31.90 & 6.42 & 203.04 \\
FinOpen & 1823 & -0.44 & 1.27 & -1.86 & 2.46 \\
YrsOffice & 1715 & 8.04 & 8.13 & 1 & 46 \\
GovCrises & 1464 & 0.16 & 0.55 & 0 & 7 \\
RegimeDur & 1604 & 13.64 & 14.62 & 0 & 100 \\
DefaultHist & 1340 & 0.43 & 0.49 & 0 & 1 \\
IMFProg & 1989 & 0.61 & 0.49 & 0 & 1 \\
\hline Notes: Table 1 reports the number of observations (Obs.), the mean duration (Mean), \\
the standard deviation (S.D.), the minimum (Min.) and the maximum (Max.) duration \\
for each spell. Similar statistics are reported for the various regressors. The data are \\
annual and comprise 121 countries over the period 1970-2011.
\end{tabular}

Table 2. Distributional analysis.

\begin{tabular}{lcccc}
\cline { 2 - 5 } & \multicolumn{2}{c}{ Markets' shutdown } & \multicolumn{2}{c}{ Markets' re-access } \\
\hline Region & \# years & Frequency $(\%)$ & \# years & Frequency (\%) \\
\hline Asia-Pacific & 375 & 37.58 & 148 & 14.83 \\
Latin America & 543 & 55.07 & 221 & 22.41 \\
Middle-East & 138 & 38.44 & 39 & 10.86 \\
Africa & 800 & 42.9 & 142 & 7.61 \\
Europe & 110 & 29.33 & 124 & 33.07 \\
North America & 23 & 54.76 & 10 & 23.81 \\
OECD & 52 & 41.27 & 44 & 34.92 \\
\hline Total & 1989 & 43.01 & 684 & 14.79 \\
\hline
\end{tabular}


Table 3. Markets' shutdown conditional on sovereign defaults.

\begin{tabular}{lcc}
\cline { 2 - 3 } & Markets' shutdown conditional on sovereign defaults \\
\hline Region & \#years & Frequency (\%) \\
\hline Asia-Pacific & 55 & 57.29 \\
Latin America & 234 & 75.48 \\
Middle-East & 26 & 50 \\
Africa & 228 & 51.01 \\
Europe & 18 & 43.9 \\
North America & 9 & 100 \\
OECD & 17 & 70.83 \\
\hline Total & 570 & 59.69 \\
\hline
\end{tabular}

Table 4. Duration of markets’ shutdown.

\begin{tabular}{lccccc}
\hline & $\mathbf{( 1 )}$ & $\mathbf{( 2 )}$ & $\mathbf{( 3 )}$ & $\mathbf{( 4 )}$ & $\mathbf{( 5 )}$ \\
\hline$p$ & $0.711^{\theta}$ & $0.719^{\theta}$ & $0.735^{\theta}$ & $0.721^{\theta}$ & $0.782^{\theta}$ \\
GDP & $(0.060)$ & $(0.061)$ & $(0.074)$ & $(0.079)$ & $(0.070)$ \\
& & $0.035^{* * *}$ & $0.040^{* *}$ & $0.050^{* *}$ & $0.047^{* * *}$ \\
Trade & & $(0.010)$ & $(0.016)$ & $(0.021)$ & $(0.016)$ \\
& & $-0.003^{* *}$ & -0.002 & -0.001 & \\
FinOpen & & $(0.001)$ & $(0.002)$ & $(0.002)$ & \\
& & $0.083^{* *}$ & $0.139^{* * *}$ & $0.130^{* *}$ & $0.154^{* * *}$ \\
YrsOffice & & $(0.039)$ & $(0.051)$ & $(0.055)$ & $(0.048)$ \\
& & & $-0.022^{* *}$ & $-0.021^{*}$ & $-0.020^{* *}$ \\
GovCrises & & & $(0.009)$ & $(0.011)$ & $(0.010)$ \\
& & & -0.145 & -0.046 & \\
RegimeDur & & & $(0.159)$ & $(0.182)$ & \\
& & & 0.006 & 0.006 & \\
DefaultHist & & & $(0.004)$ & $(0.004)$ & \\
& & & & $-0.381^{* * *}$ & $-0.336^{* * *}$ \\
IMFProg & & & & $(0.126)$ & $(0.122)$ \\
Constant & & & -0.006 & \\
& & & & $(0.147)$ & \\
\hline Observations & $1.004^{* * *}$ & $-0.888^{* * *}$ & $-0.907^{* * *}$ & $-0.905^{* * *}$ & $-0.959^{* * *}$ \\
Censored & $(0.071)$ & $(0.111)$ & $(0.168)$ & $(0.270)$ & $(0.131)$ \\
Log-Likelihood & 1989 & 1730 & 1138 & 894 & 1164 \\
SBIC & 480 & 433 & 272 & 202 & 269 \\
LRI & -1085.4 & -948.7 & -602.6 & -451.2 & -605.7 \\
\hline No & 2186.0 & 1934.7 & 1261.6 & 970.4 & 1253.8 \\
& 0.012 & 0.025 & 0.037 & 0.055 & 0.047 \\
\hline
\end{tabular}

Notes: Robust standard errors (clustered by country) for the estimated coefficients are in parentheses. Significance level at which the null hypothesis is rejected: ***, $1 \%$; **, $5 \%$; and *, $10 \%$. The sign " $\theta$ " indicates that $p$ is significantly lower than 1 using a 5\% one-sided test with robust standard errors. "Censored" indicates de number of censored observations. The Schwartz Bayesian Information Criterion (SBIC) is computed as follows: SBIC $=2[-\log L+(k / 2) \log N]$, where $\operatorname{LogL}$ is the log-likelihood for the estimated model, $k$ is the number of regressors and $N$ is the number of observations. LRI is the likelihood ration index or pseudo- $\mathrm{R}^{2}\left(\mathrm{LRI}=1-\operatorname{LogL} / \log \mathrm{L}_{0}\right.$, where $\mathrm{L}_{0}$ is the likelihood of the model with only a constant term). 
Table 5. Duration of markets' re-access.

\begin{tabular}{|c|c|c|c|c|c|}
\hline & (1) & (2) & (3) & (4) & (5) \\
\hline$p$ & $\begin{array}{c}0.728^{\theta} \\
(0.100)\end{array}$ & $\begin{array}{c}0.791^{\theta} \\
(0.105)\end{array}$ & $\begin{array}{c}0.787^{\theta} \\
(0.120)\end{array}$ & $\begin{array}{c}0.785^{\theta} \\
(0.121)\end{array}$ & $\begin{array}{c}0.781^{\theta} \\
(0.129)\end{array}$ \\
\hline GDP & & $\begin{array}{c}-0.068 * * * \\
(0.014)\end{array}$ & $\begin{array}{c}-0.068 * * * \\
(0.021)\end{array}$ & $\begin{array}{c}-0.076^{* * * *} \\
(0.029)\end{array}$ & $\begin{array}{c}-0.081 * * * \\
(0.027)\end{array}$ \\
\hline Trade & & $\begin{array}{c}-0.003 \\
(0.002)\end{array}$ & $\begin{array}{c}-0.002 \\
(0.003)\end{array}$ & $\begin{array}{c}-0.004 \\
(0.004)\end{array}$ & \\
\hline FinOpen & & $\begin{array}{c}-0.037 \\
(0.040)\end{array}$ & $\begin{array}{l}-0.036 \\
(0.048)\end{array}$ & $\begin{array}{c}-0.104 * * \\
(0.044)\end{array}$ & $\begin{array}{c}-0.104 * * \\
(0.044)\end{array}$ \\
\hline YrsOffice & & & $\begin{array}{c}0.013 \\
(0.009)\end{array}$ & $\begin{array}{c}0.017^{*} \\
(0.010)\end{array}$ & $\begin{array}{c}0.016 \\
(0.012)\end{array}$ \\
\hline GovCrises & & & $\begin{array}{c}0.587 * * * \\
(0.145)\end{array}$ & $\begin{array}{c}0.454^{* *} \\
(0.180)\end{array}$ & $\begin{array}{c}0.497 * * * \\
(0.174)\end{array}$ \\
\hline RegimeDur & & & $\begin{array}{c}0.002 \\
(0.005)\end{array}$ & $\begin{array}{c}0.003 \\
(0.006)\end{array}$ & \\
\hline DefaultHist & & & & $\begin{array}{c}0.647 * * * \\
(0.247)\end{array}$ & $\begin{array}{c}0.606 * * \\
(0.242)\end{array}$ \\
\hline IMFProg & & & & $\begin{array}{c}0.148 \\
(0.197)\end{array}$ & \\
\hline Constant & $\begin{array}{c}-0.495^{* * *} \\
(0.082)\end{array}$ & $\begin{array}{c}0.030 \\
(0.164)\end{array}$ & $\begin{array}{c}-0.099 \\
(0.233)\end{array}$ & $\begin{array}{c}-0.125 \\
(0.327)\end{array}$ & $\begin{array}{c}-0.212 \\
(0.180)\end{array}$ \\
\hline Observations & 684 & 615 & 363 & 252 & 262 \\
\hline Censored & 279 & 261 & 171 & 124 & 127 \\
\hline Log-Likelihood & -458.7 & -401.3 & -235.9 & -159.7 & -167.2 \\
\hline SBIC & 930.4 & 834.7 & 519.0 & 374.7 & 373.4 \\
\hline LRI & 0.008 & 0.043 & 0.060 & 0.085 & 0.079 \\
\hline
\end{tabular}

Table 6. Economic growth during markets' shutdown and re-access.

Sample period: 1970-2011

\begin{tabular}{lccc}
\hline \multicolumn{1}{c}{ Region } & $\begin{array}{c}\text { Average GDP growth } \\
\text { rate during markets' } \\
\text { shutdown (A) }\end{array}$ & $\begin{array}{c}\text { Average GDP growth } \\
\text { rate during markets’ } \\
\text { re-access (B) }\end{array}$ & (B)-(A) \\
\hline Asia-Pacific & 4.14 & 6.08 & 1.94 \\
Latin America & 3.45 & 4.41 & 0.96 \\
Middle-East & 5.05 & 4.36 & -0.69 \\
Africa & 3.81 & 5.75 & 1.94 \\
Europe & 2.89 & 5.15 & 2.26 \\
North America & 3.06 & 5.48 & 2.42 \\
OECD & 2.99 & 5.19 & 2.2 \\
Total & 3.69 & 5.2 & 1.51 \\
\hline
\end{tabular}


Table 7. Robustness check: Economic growth and markets’ shutdown/re-access.

\begin{tabular}{|c|c|c|c|c|}
\hline & \multicolumn{2}{|c|}{ Markets' shutdown } & \multicolumn{2}{|c|}{ Markets' re-access } \\
\hline & (1) & (2) & (3) & (4) \\
\hline$p$ & $\begin{array}{c}-0.273 * * * \\
(0.079)\end{array}$ & $\begin{array}{c}-0.269 * * * \\
(0.081)\end{array}$ & $\begin{array}{l}-0.214^{*} \\
(0.119)\end{array}$ & $\begin{array}{l}-0.204 \\
(0.115)\end{array}$ \\
\hline$G D P>0$ & $\begin{array}{c}0.071^{* * *} \\
(0.026)\end{array}$ & & $\begin{array}{c}-0.071^{*} \\
(0.040)\end{array}$ & \\
\hline$G D P<0$ & $\begin{array}{c}-0.001 \\
(0.042)\end{array}$ & & $\begin{array}{c}-0.091 \\
(0.084)\end{array}$ & \\
\hline$G D P>$ mean & & $\begin{array}{c}0.062 * * * \\
(0.022)\end{array}$ & & $\begin{array}{c}-0.064^{* *} \\
(0.032)\end{array}$ \\
\hline$G D P<$ mean & & $\begin{array}{c}0.012 \\
(0.031)\end{array}$ & & $\begin{array}{c}-0.133^{* *} \\
(0.055)\end{array}$ \\
\hline Trade & $\begin{array}{c}-0.001 \\
(0.002)\end{array}$ & $\begin{array}{c}-0.001 \\
(0.002)\end{array}$ & $\begin{array}{c}-0.004 \\
(0.004)\end{array}$ & $\begin{array}{l}-0.004 \\
(0.004)\end{array}$ \\
\hline FinOpen & $\begin{array}{c}0.134^{* *} \\
(0.056)\end{array}$ & $\begin{array}{c}0.135 * * \\
(0.056)\end{array}$ & $\begin{array}{c}-0.105^{* *} \\
(0.044)\end{array}$ & $\begin{array}{c}-0.109^{* *} \\
(0.044)\end{array}$ \\
\hline YrsOffice & $\begin{array}{c}-0.022^{* *} \\
(0.011)\end{array}$ & $\begin{array}{c}-0.021^{*} \\
(0.011)\end{array}$ & $\begin{array}{c}0.017^{*} \\
(0.010)\end{array}$ & $\begin{array}{c}0.017^{*} \\
(0.009)\end{array}$ \\
\hline GovCrises & $\begin{array}{c}-0.068 \\
(0.181)\end{array}$ & $\begin{array}{c}-0.071 \\
(0.183)\end{array}$ & $\begin{array}{c}0.459 * * * \\
(0.178)\end{array}$ & $\begin{array}{c}0.474 * * \\
(0.185)\end{array}$ \\
\hline RegimeDur & $\begin{array}{c}0.006 \\
(0.005)\end{array}$ & $\begin{array}{c}0.006 \\
(0.004)\end{array}$ & $\begin{array}{c}0.003 \\
(0.006)\end{array}$ & $\begin{array}{c}0.003 \\
(0.007)\end{array}$ \\
\hline DefaultHist & $\begin{array}{c}-0.384^{* * *} \\
(0.127)\end{array}$ & $\begin{array}{c}-0.385^{* * *} \\
(0.127)\end{array}$ & $\begin{array}{c}0.647 * * * \\
(0.249)\end{array}$ & $\begin{array}{c}0.641^{* *} \\
(0.253)\end{array}$ \\
\hline IMFProg & $\begin{array}{c}0.001 \\
(0.148)\end{array}$ & $\begin{array}{l}-0.007 \\
(0.149)\end{array}$ & $\begin{array}{c}0.139 \\
(0.201)\end{array}$ & $\begin{array}{c}0.092 \\
(0.209)\end{array}$ \\
\hline Constant & $\begin{array}{c}-1.022 * * * \\
(0.286)\end{array}$ & $\begin{array}{c}-0.949 * * * \\
(0.271)\end{array}$ & $\begin{array}{l}-0.142 \\
(0.319)\end{array}$ & $\begin{array}{l}-0.120 \\
(0.330)\end{array}$ \\
\hline Observations & 894 & 894 & 252 & 252 \\
\hline Censored & 202 & 202 & 124 & 124 \\
\hline Log-Likelihood & -450.4 & -450.4 & -159.7 & -159.1 \\
\hline SBIC & 975.5 & 975.5 & 380.2 & 378.9 \\
\hline LRI & 0.057 & 0.057 & 0.086 & 0.089 \\
\hline
\end{tabular}

